\title{
食品安全基本法
}

\author{
星野敏明*
}

日本農薬学会

（2014年6月 11 日受理）

\section{Food Safety Basic Act}

\author{
Toshiaki HosHINo \\ Pesticide Science Society of Japan, \\ 2-28-10 Nakazato, Kita-ku, Tokyo 114-0015, Japan
}

\begin{abstract}
Keywords: Food Safety Basic Act, Food Safety Commission, risk analysis, effect of food on human health, acceptable dairy intake.
\end{abstract}

\section{は じめに}

食品の安全確保に係る主要な法律は食品安全基本法, 食品 衛生法及び食品表示法であるが，そのほか，食品の製造に大 きくかかわっている農薬の規制に農薬取締法がある. 食品の 生産には, 作物の種子や苗, その他農薬や肥料といった生産 資材の製造に始まり, 作物の栽培, 収穫した収穫物の加工や 流通，販売に至る過程での衛生管理など，多くの過程を経て 食卓に上る。そのため，一つの法律で全過程を管理できるも のではなく, 複数の法律, その法律の下に管理を行う複数の 所管官庁が協力して食品の安全管理を実施している.

所管官庁の機能も, 現在はリスク評価及びリスク管理を行 う機関に役割が分担されている. 食品安全基本法は, リスク 評価を規定している法律であり, 所管する官庁は内閣府の食 品安全委員会である.ここでは, 食品安全基本法の下, 食品 安全委員会の全般的な機能を説明した後, 農薬との関わりに ついて解説する.

\section{1. 制定の背景及び目的}

2000年代初期に食品に関して, 農薬の残留, カビ毒, 腸

\footnotetext{
* ₹ 114-0015 東京都北区中里2-28-10 日本植物防疫協会ビル

E-mail: pssj_reg_science@yahoo.co.jp

(C) 日本農薬学会
}

管出血性大腸菌O157やノロウイルスによる食中毒, BSE (牛海綿状脳症), 表示等問題が次から次と発生し, 消費者の 食品に対する不安が大きく上がることとなった。

2002 年当時, 農薬に関して無登録農薬や失効農薬が輸入 野菜に残留農薬基準を超える濃度で検出されたり, 個人的に 輸入され国内農産物の栽培に使用されたりと食品安全に対す る問題が発生し, 農業, 農産物の安全への信頼性が失われた ことから，より消費者への保護を目指し，2003年（平成 15 年）に農薬取締法, 食品衛生法等が改正され，ポジティブリ スト制度へ移行し, 食品の安全性が図られるようになった (本シリーズ「食品衛生法」を参照)。合わせて, 食品の安全 性及びその信頼性の確保のため, また国の施策の決定手順を より透明化するため, 食品の安全に係わる所管官庁の組織, 役割が見直され, リスク評価, リスク管理及びリスクコミュ ニケーションといった役割分担が明確化された。このような 状況下, 国民の健康の保護を最優先とすることなどを基本 理念とする食品安全基本法 (2003年5月23日公布, 最終改 正2011年6月24日）が2003年7月 1 日に施行され，同時に， 科学的知見に基づき客観的・中立的なリスク評価機関として 内閣府に食品安全委員会を, 管理側の行政機関から独立させ て設置した，農林水産省，厚生労働省は食品安全委員会のリ スク評価に基づき，管理措置を施すリスク管理機関として役 割が見直された。 
食品安全基本法: 2003 年 7 月 1 日施行

食品衛生法（改正）：2003年5月30日施行,

2006年5月29日ポジティブリスト

制度施行

農薬取締法（改正）：2003年7月 1日施行

\section{2. 主な内容及び解説}

\section{1. 食品安全基本法の制定}

食品安全基本法は，「国民の健康の保護が最重要である」 ことを基本理念として, 生産から消費に至る過程の食品の安 全性の確保に関する施策を総合的に推進することを目的とし た枠組みを規定している，特に，国民の健康の保護のため, 事業者ではなく消費者の保護を優先し，国，地方公共団体， 食品事業者の責務や消費者の役割を明らかにした（後述）. また，国の施策の決定プロセスを透明化し，リスクの評価と 管理を行う機関を明確化したことが特徵である.

食品安全基本法の主たる機能は，食品に含まれる危害要因

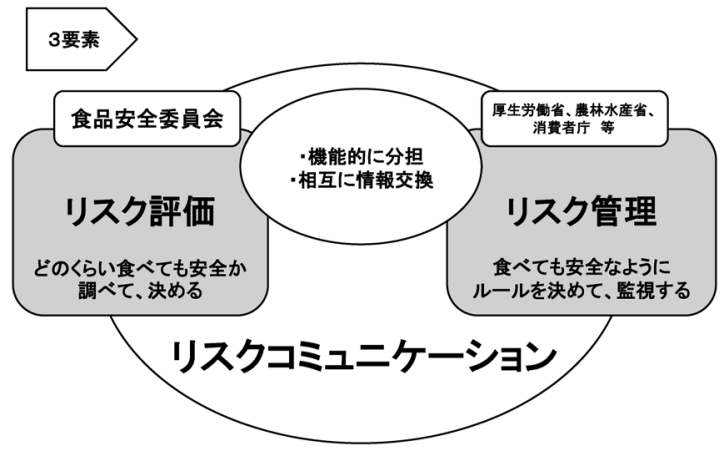

図1.リスク分析 ${ }^{1)}$.【リスク分析】：食品中に含まれる危害要因 （ハザード）を摂取することによってヒトの健康に悪影響を及ぼ す可能性がある場合に，その発生を防止し，またはそのリスクを 低減するための考え方. リスク管理，リスク評価及びリスクコ ミュニケーションの3つの要素からなっており,これらが相互に 作用しあうことによって，より良い成果が得られる。
（有害な微生物や化学物質等）を摂取することによって人の 健康に悪影響を及ぼす可能性がある場合に，その発生を未然 に防止し，またはそのリスクを最小限にするための枠組みで ある「リスク分析」という考え方が取り入れられている.

リスク分析は「リスク評価」，「リスク管理」，「リスクコ ミュニケーション」の3つの要素からなっており, この考え 方に基づき各府省庁等が役割を分担している.リスク評価は 内閣府・食品安全委員会が，リスク管理は農林水産省，厚生 労働省, 環境省等が, リスクコミュニケーションは消費者庁 のほか，各省庁が実施している $\left(\right.$ 図 $\left.1^{1)}\right)$.

\section{2. 食品安全に係るリスク分析の機能と組織}

食品の安全性の確保に際し, 食品の生物学的, 化学的, 物 理的な要因・状態からヒトの健康に悪影響を及ぼすおそれが ある場合には，人の健康に及ぼす影響についての評価（以下 「食品健康影響評価」という.）を要因ごとに行われなければ ならないと規定されている(第11条).

この目的のために, 内閣府に食品安全委員会が置かれた (第22条).

関係各大臣は，食品健康影響に係る事項がある場合には食 品安全委員会の意見を聴かなければならないとされている (第24条).

表 1 に農薬に係る関係所管官庁の種類と役割を示す.

2.2.1. リスク評価機関：食品安全委員会

食品安全委員会は, 科学的知見に基づき客観的かつ中立・ 公正な立場からリスク評価（食品健康影響評価）を実施する ことを最も重要な役割として実施する機関であり，厚生労働 省や農林水産省などのリスク管理機関から独立している．農 林水産省, 厚生労働省は食品安全委員会のリスク評価に基づ き，リスク管理措置を施す役割を果たしている.

また，リスクコミュニケーションも重要な役割である.

リスク評価とは, 食品安全委員会のホームページに以下の ように記載されている。

表 1. 農薬に係る主要所管官庁が担当する法律と役割

\begin{tabular}{|c|c|c|}
\hline 所管官庁 & 法律 & 事項 \\
\hline $\begin{array}{l}\text { 食品安全委員会 } \\
\text { (リスク評価機関) }\end{array}$ & 食品安全基本法 & $\begin{array}{l}\text { 安全性評価が実施され, 許容一日摂取量（ADI）が設定される（食品安全基本法第 } \\
11 \text { 及び } 24 \text { 条). }\end{array}$ \\
\hline $\begin{array}{l}\text { 農林水産省 } \\
\text { （リスク管理機関） }\end{array}$ & 農薬取締法 & $\begin{array}{l}\text { 農薬登録を申請する会社が必要な試験成績を付けて申請する. 残留農薬基準設定に } \\
\text { は作物残留試験成績が用いられる.作物残留試験の実施は農薬取締法 (第 } 2 \text { 条), } \\
\text { 農林水産省通知等で規定される. 農薬登録申請, 農薬登録及び使用基準の設定等 } \\
\text { が行われる. }\end{array}$ \\
\hline $\begin{array}{l}\text { 厚生労働省 } \\
\text { (リスク管理機関) }\end{array}$ & 食品衛生法 & 作物残留試験成績に基づき，残留農薬基準が設定される（食品衛生法第11条)。 \\
\hline $\begin{array}{l}\text { 環境省 } \\
\quad \text { （リスク管理機関） }\end{array}$ & 環境省告示 & $\begin{array}{l}\text { 農薬登録保留基準が規定されている.（読み物企画「農薬取締法3. 主な内容と解説」 } \\
\text { を参照のこと.） }\end{array}$ \\
\hline
\end{tabular}


表2. 食品健康影響評価の審議状沉 ${ }^{3}$

\begin{tabular}{|c|c|c|c|c|c|c|c|c|}
\hline 区分 & 要請件数 & $\begin{array}{c}\text { うち } \\
26 \text { 年度分 }\end{array}$ & 自ら評価 & 合計 & 評価終了 & $\begin{array}{c}j ち \\
26 \text { 年度分 }\end{array}$ & $\begin{array}{l}\text { 意見 } \\
\text { 募集中 }\end{array}$ & 審議中 \\
\hline 添加物 & 147 & 1 & 0 & 147 & 132 & & 1 & 14 \\
\hline 農薬 & 965 & 2 & 0 & 965 & 673 & 20 & 6 & 286 \\
\hline うちポジティブリスト関係 & 484 & & 0 & 484 & 262 & 10 & 3 & 219 \\
\hline うち清涼飲料水 & 33 & & 0 & 33 & 33 & & 0 & 0 \\
\hline うち飼料中の残留農薬基準 & 42 & & 0 & 42 & 10 & & 0 & 32 \\
\hline 動物用医薬品 & 482 & 99 & 0 & 482 & 339 & 6 & 2 & 141 \\
\hline うちポジティブリスト関係 & 108 & & 0 & 108 & 65 & 3 & 2 & 41 \\
\hline 化学物質・污染物質 & 59 & & 3 & 62 & 57 & & 0 & 5 \\
\hline うち清涼飲料水 & 49 & & 0 & 49 & 46 & & 0 & 3 \\
\hline 器具・容器包装 & 16 & & 0 & 16 & 8 & 1 & 0 & 8 \\
\hline 微生物・ウイルス & 10 & & 2 & 12 & 11 & & 0 & 1 \\
\hline プリオン & 30 & & 16 & 46 & 37 & 1 & 0 & 9 \\
\hline かび毒・自然毒等 & 7 & & 2 & 9 & 9 & & 1 & 0 \\
\hline 遺伝子組換え食品等 & 208 & & 0 & 208 & 183 & 3 & 4 & 21 \\
\hline 新開発食品 ～～～～～～～～～～ & 80 & 2 & 1 & 81 & 71 & & 2 & 10 \\
\hline 肥料・飼料等 & 168 & 2 & 0 & 168 & 103 & & 7 & 58 \\
\hline うちポジティブリスト関係 & 100 & & 0 & 100 & 55 & & 2 & 43 \\
\hline 肥飼料・微生物合同 & $1(34)$ & & 0 & 1 & $1(12)$ & & 0 & 0 \\
\hline $\begin{array}{l}\text { 高濃度にジアシルグリセロールを含む食品に } \\
\text { 関するワーキンググループ }\end{array}$ & 1 & & 0 & 1 & 0 & & 0 & 1 \\
\hline $\begin{array}{l}\text { 食品による窒息事故に関するワーキンググ } \\
\text { ループ }\end{array}$ & 1 & & 0 & 1 & 1 & & 0 & 0 \\
\hline $\begin{array}{l}\text { 放射性物質の食品健康影響に関するワーキン } \\
\text { ググルーフ }\end{array}$ & 1 & & 0 & 1 & 1 & & 0 & 0 \\
\hline 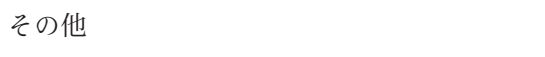 & 1 & & 1 & 2 & 1 & & 0 & 1 \\
\hline 合計 & 2,177 & 106 & 25 & 2,202 & 1,627 & 31 & 23 & 555 \\
\hline
\end{tabular}

平成26年6月13日現在．表内の注䣋は省略した.

リスク評価（食品健康影響評価 $)^{2)}$

私たちは，一日たりとも食べ物を食べない日はあり ません，私たちが口にする食べ物には，豊かな栄養や 成分とともに，ごく微量ながら健康に悪影響を及ぼす 要因が含まれていることがあります。

「リスク評価」とは，リスク（食品を食べることに よって有害な要因が健康に及ぼす悪影響の発生確率と 程度）を科学的知見に基づいて客観的かつ中立公正に 評価することです．評価は，化学物質や微生物等の要 因ごとに行われ，本委員会の第一義的な役割となって います。

リスク評価の結果に基づき, 食品の安全性の確保の ため講ずべき施策について, 内閣総理大臣を通じて関 係各大臣に勧告を行うことができます。
食品安全委員会のリスク評価は, 添加物, 農薬, 動物用医 薬品, 器具 - 容器包装, 化学物質 - 污染物質, 微生物 - ウイ ルス, ブリオン, カビ毒・自然毒等, 遺伝子組換え食品等, 新開発食品, 肥料・飼料等の 11 分野で実施されている. 各

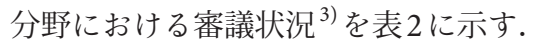

2.2.2. リスク管理機関 : 厚生労働省, 農林水産省

2.2.2.1. 厚生労働省

厚生労㗢省は食品衛生法に基づき, 食品, 添加物等の製 造, 輸入, 販売における衛生規制を講じている. 食品衛生法 （本シリーズ「食品衛生法」を参照されたい）では, 飲食に 起因する衛生上の危害の発生を防止し, 国民の健康を保護す ることを目的としており, 厚生労働省は, 食品中の放射性物 質, 残留農薬, 添加物, 污染物質等に関する対策, 食中毒, 牛海綿状脳症 (BSE), 遺伝子組換え食品, 輸入食品, 健康 食品の安全確保など監視指導を実施している地方公共団体と 連携して, 食品の安全性のためのリスク管理を行っている. 
食品中の残留農薬の規制に関して, 食品安全委員会が実施 した食品健康影響評価結果に基づき, 厚生労働省は食品衛生 法に基づき残留農薬基準を設定し, 残留基準に適合しない食 品は, 輸入や販売等が禁止される.

農薬の登録, 残留農薬基準の設定に先立ち, 食品安全基本 法に基づき, 食品安全委員会において食品健康影響評価が実 施され，一日摂取許容量（ADI: Acceptable Daily Intake）が 設定されなければならない。

食品の安全性に関する用語集 ${ }^{4)}$ より抜粋

一日摂取許容量（ADI）：ヒトがある物質を毎日一生涯 にわたって摂取し続けても，現在の科学的知見から見 て健康への悪影響がないと推定される一日当たりの摂 取量のこと．通常の単位は $\bigcirc \mathrm{mg} / \mathrm{kg}$ 体重/日（体重 $1 \mathrm{~kg}$ 当たりの量)。

ヒトがある物質を毎日一生涯にわたって摂取し続けて も, 現在の科学的知見から見て健康への悪影響がない と推定される一日当たりの摂取量のこと。通常の単位 は○ $\mathrm{mg} / \mathrm{kg}$ 体重/日（体重 $1 \mathrm{~kg}$ 当たりの量）.

無毒性量（NOAEL, No Observed Adverse Effect Level） ある物質について何段階かの異なる投与量を用いて毒 性試験を行ったとき，有害影響が認められなかった最 大の投与量のこと，通常は，さまざまな動物試験にお いて得られた個々の無毒性量の中で最も小さい值を, その物質の無毒性量とする。

安全係数 (Safety Factor, 不確実係数UF, Uncertainty Factor ともいう)

動物実験のデータを用いてヒトへの毒性を推定する場 合，通常，動物とヒトとの種の差として「10倍」，さら にヒトとヒトとの間の個体差として「10倍」の安全率 を見込み，それらをかけ合わせた「100倍」を安全係数 として用いる。

ADIは，無毒性量を安全係数で割ることで求める.

食品中の残留農薬基準は，農薬の使用基準（使用方法）に 基づいた作物毎の残留試験の結果から，最大の残留濃度を予 測し，安全係数を考慮して，日本全国のどこで栽培しても超 えない濃度 (残留農薬基準) を推定し, 日本人の 1 日当たり の各食品の摂取量から, 各農薬の 1 日当たりの摂取量を推定 し，それがADIの $80 \%$ を超えていないことを確認して設定 される。

\subsubsection{2. 農林水産省}

農林水産省では, リスク管理部門を産業振興部門から分離 させ，食品分野における消費者行政とリスク管理を担う「消 費・安全局」を設置した，消費安全局が設置された経緯につ いて，農林水産省の文書に以下のように記載されている。 2003年7月, リスク分析の考え方を導入するなど食品の安
全性の確保に関する基本理念等を定めた食品安全基本法が施 行され，科学的知見に基づき，中立的なリスク評価を行う組 織として内閣府に食品安全委員会が設置された。農林水産省 においても，リスク管理等食品の安全に係る政策を強化する ため, 消費・安全局が設置された，食品安全に係るリスク管 理は(1)リスク管理の初期作業（食品安全における問題点の特 定，危害要因の優先度の分類，リスク評価の依頼等)，(2) スク管理措置の検討・実施（リスク評価の結果をもとに，リ スク低減のための措置について技術的な実行可能性, 費用対 効果等を検討し, 適切な措置を実施), (3)措置の検証・見直 し（リスク管理措置の有効性の検証・措置の再検討）からな $る^{5)}$

農林水産省及び農薬取締法に関しては，本シリーズ「農薬 取締法」を参照されたい。農林水産省では, 食品の安全確保 の取組として, 食品中の有害な化学物質や微生物について実 態調査を行い, 健康への悪影響が懸念される場合には, 施策 を実施し, また, 生産段階における取組として, 農業生産工 程管理（GAP: Good Agricultural Practice）及び食品製造事 業者の HACCP（Hazard Analysis Critical Control Point）を 導入し，生産製造管理を促進している。このような取組につ いて, 関係府省庁と連携し, リスクコミュニケーションを実 施している.

2.2.3. リスクコミュニケーション

リスクコミュニケーションは, リスク評価やリスク管理と ともに食品の安全性に関するリスク分析の3要素の1つであ り, リスク評価機関である食品安全委員会, リスク管理機関 である厚生労働省, 農林水産省及び環境省, 消費者庁が連 携・協力して，リスク評価やリスク管理の決定に関してパブ リックコメント等による国民の意見募集や，消費者，生産 者, 食品関連事業者, 行政等の関係者間での意見交換からリ スクコミュニケーションが行われている.

\section{3. 食品安全基本法の条文の解説}

各条文のうち，農薬に関連する事項について解説する。 食品安全基本法の全体の構成を表 3 に示す。

第 1 条: 目的

食品安全基本法はその目的を以下のように定め, 食品の安 全性確保の施策を総合的に推進することが詔われている。

$\Gamma$ (目的) 第 1 条この法律は, 科学技術の発展, 国際化の進 展その他の国民の食生活を取り巻く環境の変化に適確に対応 することの緊要性にかんがみ, 食品の安全性の確保に関し, 基本理念を定め, 並びに国, 地方公共団体及び食品関連事業 者の責務並びに消費者の役割を明らかにするとともに，施策 の策定に係る基本的な方針を定めることにより，食品の安全 性の確保に関する施策を総合的に推進することを目的とす る.」 
第 3 条から第 5 条 : 基本的理念

食品安全基本法では, 食品の安全性の確保に以下の 3 点が 重要と位置付けている.

1. 国民の健康の保護が最も重要であるという基本的認識 (第3 条)

2. 食品供給工程の各段階における適切な措置の実施（第 4

条)

3. 国際的動向及び国民の意見に配慮しつつ科学的知見に 基づいて国民の健康への悪影響を未然に防止する（第5 条)

第6条から第9条：国・地方自治体・食品関連事業者の責 務, 消費者の役割

食品安全基本法の基本理念にのっとり, 国, 地方自治体及 び食品関連事業者の責務と消費者の役割が表4のように規定 された。

第 11 条：食品健康影響評価

第11条に食品健康影響評価とは，「食品の安全性の確保に 関する施策の策定に当たっては，人の健康に悪影響を及ぼす おそれがある生物学的, 化学的若しくは物理的な要因又は状

表3. 食品安全基本法の概要

\begin{tabular}{l}
\hline 第 1 章一総則（第 1 条〜第 10 条） \\
第 1 条一目的 \\
第 3 条〜第 5 条一食品の安全性に確保についても基本理念 \\
第 6 条〜第 9 条一国, 地方自治体及び食品関連事業者の責 \\
務と消費者の役割 \\
第2章一施策の策定に係る基本的な方針（第 11 条〜第 21 条） \\
第 11 条一食品健康影響評価の実施 \\
第 12 条〜章一食品安全委員会（第 22 条〜第 38 条） \\
第 22 条一食品安全委員会の設置 \\
第 23 条一食品安全委員会の所掌事務 \\
第 24 条一食品安全委員会の意見の聴取 \\
附則
\end{tabular}

態であって, 食品に含まれ, 又は食品が置かれるおそれがあ るものが当該食品が摂取されることにより人の健康に及ぼ す影響についての評価」と規定され，施策ごとに行われなけ ればならないとされている。第11条では, 健康影響評価の 実施の例外が規定（第11条第 1 項第 1 3 号）されているが, ここではその説明は省略する。

第 12 条〜第 20 条：施策の策定に当たっての留意事項

第 13 条では情報及び意見の交換の促進として,「食品の安 全性の確保に関する施策の策定に当たっては, 当該施策の策 定に国民の意見を反映し，並びにその過程の公正性及び透明 性を確保するため, 当該施策に関する情報の提供, 当該施策 について意見を述べる機会の付与その他の関係者相互間の情 報及び意見の交換の促進を図るために必要な措置が講じられ なければならない.」とリスクコミュニケーションの実施が 明確に規定された.

また, 第19条では, 「食品の安全性の確保に関する広報活 動の充実により国民が食品の安全性の確保に関する知識と理 解を深めるために必要な措置が講じられなければならない.」 と規定され, 食品の安全性の確保に関して国民に対する教 育, 学習の振興が謳われた.

第 22 条: 食品安全委員会の設置

食品安全委員会は, 厚生労働省, 農林水産省等のリスク管 理機関から独立して, 中立・公正な立場からリスク評価（食 品健康影響評価）を実施することから, 内閣府に設置され た.

第23条：食品安全委員会の所掌事務

食品安全委員会は, 関係大臣の要請により意見の聴取が行 われ，食品健康影響評価を実施するが，そのほか，自らの判 断で健康影響評価を行うことができるとしている，具体的に は, 牛海綿状脳症 (BSE), かび毒のデオキシニバレノール, ニバレノール，オクラトキシン $\mathrm{A}$ 等が評価されつつある.

表4. 食品安全基本法 : 国, 地方自治体及び食品関連事業者の責務と消費者の役割

国の責務（第6条）

地方公共団体の責務（第7条）

食品関連事業者の責務（第 8 条）

消費者の役割（第9条）
食品の安全性の確保に関する施策を総合的に策定・実施する責務を有する

国との適切な役割分担をろまえ，区域の自然的経済的社会的諸条件に応じた施策を策定・実施する責務を 有する

(1)食品の安全性の確保について第一義的な責任を有していることを認識し, 食品供給行程の各段階におい て必要な措置を適切に講ずる責務を有する

(2)正確かつ適切な情報の提供に努める

(3)国，地方公共団体が実施する施策に協力する責務を有する

食品の安全性の確保に関し知識と理解を深めるとともに, 施策について意見を表明するように努めること によって, 食品の安全性の確保に積極的な役割を果たす 
第 24 条：食品安全委員会の意見の聴取

関係各大臣は, 食品健康影響に関わる事項がある場合は食 品安全委員会の意見を聴かなければならないとされている.

農薬に係わる具体例として, 厚生労働省では, 食品衛生法 に関連して基準若しくは規格を定めょうとするとき等に，ま た，農林水産省では，農薬取締法に関連して特定農薬の指定 若しくは変更，また，農作物及び土壌の農薬登録保留基準を 定め若しくは変更する場合等が該当する.

\section{4. 食品健康影響評価に係わる 最近の話題及び今後の課題}

\section{1. 急性参照量 (ARfD)}

急性参照用量（ARfD: acute reference dose）とは，「ヒト がある物質を 24 時間又はそれより短い時間経口摂取した場 合に健康に悪影響を示さないと推定される一日当たりの摂取 量」元である.

食品安全委員会農薬専門調査会において「農薬の急性参照 用量設定における基本的考え方（平成26年 2 月 14 日農薬専 門調査会決定) $\rfloor^{6)}$ が提示され，その資料「1. はじめに」に は以下のように記載されている。

「現在, 我が国における農薬のリスク評価は, 長期間の経 口摂取により健康に及ぼす影響の指標として一日摂取許容量 （ADI）を設定することを主眼として行われているが，当該 農薬の代謝及び毒性の性質・程度によっては，短期間の経口 摂取においても，摂取により健康に及ぼす影響が懸念される 農薬も存在する。

短期間の経口摂取，すなわちある農薬が一定量を超え高濃 度に残留する食品を一日以内（又は一時的）に大量に摂取し た場合のヒトの健康に及ぼす影響を評価する際にADIを指 標とすることは，過大評価となる可能性があるなど実態に即 しておらず，より適切な評価指標を用いるべきである.

これまで, 農薬の短期間の摂取により健康に及ぼす影響 については，国際的にもJMPR等多くの評価機関において 評価が実施されており，その評価指標として急性参照用量 (ARfD) が用いられている.

このような状況を踏まえ，本資料では，食品安全委員会農 薬専門調査会において，農薬の短期間の摂取による食品健康 影響評価を行う際の指標として，ARfDを設定するに当たっ ての考え方を整理した.」

上記の資料によると, 今後, 食品安全委員会では原則とし て全ての評価対象農薬に対して急性参照量の設定を行うとの 基本方針が提出された。

また，農林水産省主催の「第 10 回農薬登録制度に関す る懇談会」（2014年3月17日開催）では「急性参照用量 （ARfD）の設定及び短期摂取量推定の導入について」が協議 され，今後，急性参照用量（ARfD）の設定を進めていくこ とについて, 食品安全委員会, 厚生労働省, 農林水産省は合
意されたものと考えられる，農林水産省ホームページに第 10 回農薬登録制度に関する懇談会の資料 ${ }^{7)}$ が添付されてい る.急性参照量は新しい考え方なので，それらの資料を熟読 されたい.

\section{5. さらに詳しく知るために}

\section{参考資料}

- 食品安全基本法

http://law.e-gov.go.jp/htmldata/H15/H15HO048.html

・食品安全委員会機関誌「食品安全」

http://www.fsc.go.jp/sonota/kikansi/kikansi.html

- 食品安全委員会「食品の安全性に関する用語集（第4版）」 http://www.fsc.go.jp/yougoshu/yougoshu_fsc.pdf

・消費者庁「ハンドブック消費者2014」 http://www.caa.go.jp/adjustments/pdf/2014handbook.pdf

- 吉田ら：日本における農薬等の急性参照用量設定の基本的 考え方．食品衛生学雑誌 54(4)331-334, 2013

- Yoshida et al.: Simulation of acute reference dose (ARfD) settings for Pesticides in Japan, J. Toxicol. Sci. 38(2) 205214,2013

\section{・ウェブサイト（消費者庁「ハンドブック消費者 2014$\rfloor^{8)}$ よ} り)

・食品安全委員会

http://www.fsc.go.jp/

委員会や意見交換会等の資料や概要，食中毒等特定のト ピックに関する科学的知見等を掲載. 特に国民の関心が高 いと考えられる事案については,「重要なお知らせ」又は 「お知らせ」を活用して情報提供.

- 厚生労働省

http://www.mhlw.go.jp/topics/bukyoku/iyaku/syokuanzen/index.html\#top 報道発表資料, 食品の安全に関する Q\&A，審議会等の会 議資料，食品安全に関する施策の情報などを掲載.

・農林水産省消費・安全局 http://www.maff.go.jp/j/syouan/index.html 食品の安全や消費者の信頼確保のための農林水産省の施策 について情報提供.

\section{・メールマガジン（消費者庁「ハンドブック消費者 2014$\rfloor^{8)}$ より)}

・食品安全委員会e-マガジン

http://www.fsc.go.jp/sonota/e-mailmagazine/e_new_ mailmagazine.html

・農林水産省食品安全エクスプレス http://www.maff.go.jp/j/syouan/johokan/mail_magagine. html 
毎日（月～金)，農林水産省を始め各府省庁が発出する報 道発表資料を中心に, 食品の安全及び消費者の信頼確保に 関係する情報提供.

・農林水産省消費者の部屋 http://www.maff.go.jp/j/heya/index.html 食料, 農林水産業・食品産業, 農山漁村等についての情報 提供.

\section{引用 資 料}

1）パンフレット「食品安全委員会」, p. 1, 2013 http://www.fsc. go.jp/sonota/pamphlet/2013/pamphlet2013_japall.pdf 2014年6 月 2 日閲覧

2) 食品安全委員会: 食品安全委員会（FSC）とは 食品安全委員会 の役割, http://www.fsc.go.jp/iinkai/mission.html 2014年6月 2
日閲覧

3）食品安全委員会: 食品健康影響評価の審議状況, $2014 \mathrm{http} / / /$ www.fsc.go.jp/hyouka/2014年6月2日閲覧

4）食品安全委員会：食品の安全性に関する用語集, 2008 http:// www.fsc.go.jp/yougoshu/visual_yogoshu.pdf 2014年6月2日閲覧

5）農林水産省：平成19年度農林水産省年報 第 5 章 消費 - 安全局, 2007 http://www.maff.go.jp/j/pr/annual/2007/pdf/capter08.pdf 2014年6月 2 日閲覧

6）食品安全委員会農薬専門調査会：農薬の急性参照用量設定におけ る基本的考元方, 2014 http://www.fsc.go.jp/senmon/nouyaku/ kettei_tou/07_nouyaku_arfd.pdf 2014年6月 2 日閲覧

7）農林水産省：農薬登録制度に関する懇談会 第10回懇談会（平成 26年3月 17 日開催）資料 http://www.maff.go.jp/j/nouyaku/n_ kaigi/10/index.html 2014年6月2日閲覧

8）消費者庁：ハンドブック消費者, 2014 http://www.caa.go.jp/ adjustments/handbook.html２014年6月2日閲覧 